\title{
Efficiency of utilization of heat of moisture from exhaust gases of heat HRSG of CCGT
}

\author{
Nikolay Galashov ${ }^{1, *}$, Svyatoslav Tsibulskiy ${ }^{1}$, Denis Mel'nikov ${ }^{1}$, Alexandr Kiselev ${ }^{1}$, and \\ Al'bina Gabdullina' ${ }^{1}$ \\ ${ }^{1}$ National Research Tomsk Polytechnic University, 634050 Tomsk, Russia
}

\begin{abstract}
The paper discusses the technology of utilizing the heat of exhaust gas moisture from heat recovery steam gases (HRSG) of combined-cycle gas turbine (CCGT). Particular attention focused on the influence of the excess air factor on the trapping of the moisture of the exhaust gases, as in the HRSG of the CCGT its value varies over a wider range than in the steam boilers of the TPP. For the research, has been developed a mathematical model that allows to determine the volumes of combustion products and the amount of water vapor produced according to a given composition of the burned gas and determine the amount of moisture that will be obtained as a result of condensation at a given temperature of the flue gases at the outlet of the condensation heat exchanger (CHE). To calculate the efficiency of the HRSG taking into account the heat of condensation of moisture in the CHE an equation is derived.
\end{abstract}

\section{Introduction}

CCGT of the utilization type currently has the highest net efficiency in the generation of electricity, which at the most powerful and perfect CCGT 9.02.02 of GE Power has reached $63.7 \%$. The working medium of the steam turbine unit of this CCGT is water. The ways to further increase the efficiency of the CCGT are given in following work [1]. This is an increase in the initial temperature in front of the gas turbine and a decrease in heat losses in the steam turbine cycle and HRSG. At the same time, a decrease in heat loss in HRSG is the simplest way.

The combustion of a hydrocarbon fuel, depending on the type of fuel in the exhaust gases is formed about $10-15 \%$ moisture vapor. To prevent condensation of this moisture in the flues and the chimney so that there is no corrosion and destruction of the equipment, the exhaust gases are withdrawn at a temperature above the dew point. In this case, the heat of condensation of water vapor is lost and the atmosphere is contaminated with them.

The technology of cooling off gases in boilers below the dew point using condensation heat recovery units is now recognized as one of the most energy efficient [2-6].

This technology is especially important for HRSG of CCGT, their efficiency is not more than $90 \%$ due to the low temperature of the gases entering the boiler. At the same

\footnotetext{
Corresponding author : gal@tpu.ru
} 
time, HRSG of CCGT operate with an excess air factor $\alpha$ greater than 2, and the articles on this topic consider the operation of boilers with $\alpha<2$. For cooling of flue gases in CHE, can be used low-boiling substances and can be obtained additional generation of electricity based on the Rankine organic cycle with an air condenser [7-10].

To evaluate the effect on the amount of moisture captured and on the efficiency of the HRSG fuel characteristics, the operating parameters of the flue gases and the air excess factor, a mathematical model is worked out for the operation of the HRSG with a CCGT.

\section{Mathematical model of calculating the HRSG with CHE}

The mathematical model of the HRSG with CHE represents a system of equations for calculating the parameters and indicators of its operation.

The initial data:

- gas composition;

- air moisture content $d_{\text {air }}, \mathrm{kg} / \mathrm{kg}$.dry;

- temperature $t_{0},{ }^{\circ} \mathrm{C}$ and pressure $P_{\mathrm{g}}, \mathrm{Pa}$ exhaust gases at the input of the recovery boiler $t_{1}$ and $t_{2}$;

- coefficient of excess air in the HRSG $\alpha$.

The following constants are used in the model:

Molar mass $(\mathrm{kg} / \mathrm{mol})$ : water $\mu_{\mathrm{H} 2 \mathrm{O}}=18.016$; nitrogen $\mu_{\mathrm{N} 2}=28.013$; oxygen $-\mu_{\mathrm{O} 2}=32.0$; argon $\mu_{\mathrm{Ar}}=39.95$; carbon dioxide $-\mu_{\mathrm{CO} 2}=44.0$.

$R=8314.41 \mathrm{~J} /(\mathrm{mol} \cdot \mathrm{K})$ - universal gas constant;

Take volume fractions of elements of dry air: nitrogen $r_{\mathrm{dryN} 2}=0.7812$; oxygen $r_{\mathrm{dryO} 2}=0.2096$; argon $r_{\mathrm{dryAr}}=0.0092$. Because of the low content, don't take into account the fraction of carbon dioxide. Molar mass of dry air: $\mu_{\text {dry.air }}=\mu_{\mathrm{N} 2} r_{\text {dry } 2}+\mu_{\mathrm{O} 2} r_{\text {dry } 2}+\mu_{\text {Ar }} r_{\text {dryAr }}=28.96 \mathrm{~kg} / \mathrm{mol}$.

Ratio $\mu_{\mathrm{H} 2 \mathrm{O}} / \mu_{\text {dry.air }}=0.622$.

Volume fraction of moist air: moisture $r_{\mathrm{mH} 2 \mathrm{O}}=d_{\text {air }} /\left(0.622+d_{\text {air }}\right)$; nitrogen $r_{\mathrm{mN} 2}=0.622 r_{\mathrm{dryN} 2} /\left(0.622+d_{\text {air }}\right) ; \quad$ oxygen $\quad r_{\mathrm{mO} 2}=0.622 r_{\mathrm{dryO} 2} /\left(0.622+d_{\text {air }}\right) ; \quad$ argon $r_{\mathrm{mAr}}=0.622 r_{\text {dryAr }} /\left(0.622+d_{\text {air }}\right)$.

\subsection{Calculation of the composition of combustion products and it enthalpies at the input of the HRSG}

Table 1. Equations for properties of combustion products at the input of the HRSG.

\begin{tabular}{|c|c|c|}
\hline $\begin{array}{l}\text { In- } \\
\text { dex }\end{array}$ & Determined rate & Equation \\
\hline 1 & $\begin{array}{l}\text { Theoretical volume of air required } \\
\text { for complete combustion of fuel } \\
\text { under normal conditions }\end{array}$ & $\begin{array}{c}V_{0}=0.0476\left(0.5 \mathrm{CO}+0.5 \mathrm{H}_{2}+1.5 \mathrm{H}_{2} \mathrm{~S}+2 \mathrm{CH}_{4}+3.5 \mathrm{C}_{2} \mathrm{H}_{6}+5 \mathrm{C}_{3} \mathrm{H}_{8}\right. \\
\left.+6.5 \mathrm{C}_{4} \mathrm{H}_{10}-\mathrm{O}_{2}\right), \mathrm{nm}^{3} / \mathrm{nm}^{3}\end{array}$ \\
\hline 2 & $\begin{array}{l}\text { Theoretical volume of nitrogen in } \\
\text { the combustion of } 1 \mathrm{~nm}^{3} \text { of fuel }\end{array}$ & $V_{0 . \mathrm{N} 2}=0.79 V_{0}+0.01 \mathrm{O}_{2}, \mathrm{~nm}^{3} / \mathrm{nm}^{3}$ \\
\hline 3 & $\begin{array}{l}\text { Theoretical volume of nitrogen in } \\
\text { the combustion of } 1 \mathrm{~nm}^{3} \text { of fuel }\end{array}$ & $\begin{array}{c}V_{0 . \mathrm{RO} 2}=0.01\left(\mathrm{CO}+\mathrm{H}_{2} \mathrm{~S}+\mathrm{CH}_{4}+2 \mathrm{C}_{2} \mathrm{H}_{6}+3 \mathrm{C}_{3} \mathrm{H}_{8}+4 \mathrm{C}_{4} \mathrm{H}_{10}\right), \\
\mathrm{nm}^{3} / \mathrm{nm}^{3}\end{array}$ \\
\hline 4 & $\begin{array}{l}\text { Theoretical volume of } \mathrm{H}_{2} \mathrm{O} \text { in the } \\
\text { combustion of } 1 \mathrm{~nm}^{3} \text { of fuel }\end{array}$ & $\begin{array}{c}V_{0 . \mathrm{H} 2 \mathrm{O}}=0.01 \cdot\left(\mathrm{H}_{2} \mathrm{~S}+\mathrm{H}_{2}+2 \mathrm{CH}_{4}+3 \mathrm{C}_{2} \mathrm{H}_{6}+4 \mathrm{C}_{3} \mathrm{H}_{8}+5 \mathrm{C}_{4} \mathrm{H}_{10}\right)+1.61 \\
V_{0}, \mathrm{~nm}^{3} / \mathrm{nm}^{3}\end{array}$ \\
\hline 5 & $\begin{array}{l}\text { Theoretical volume of gases during } \\
\text { combustion of } 1 \mathrm{~nm}^{3} \text { of fuel }\end{array}$ & $V_{\mathrm{g}}=V_{0 . \mathrm{N} 2}+V_{0 . \mathrm{RO} 2}+V_{0 . \mathrm{H} 2 \mathrm{O}}+(\alpha-1) V_{0}, \mathrm{~nm}^{3} / \mathrm{nm}^{3}$ \\
\hline 6 & $\begin{array}{l}\text { Actual volume of } \mathrm{H}_{2} \mathrm{O} \text { in the com- } \\
\text { bustion of } 1 \mathrm{~nm}^{3} \text { of fuel }\end{array}$ & $V_{\mathrm{H} 2 \mathrm{O}}=V_{0 . \mathrm{H} 2 \mathrm{O}}+0.0161(\alpha-1) V_{0}, \mathrm{~nm}^{3} / \mathrm{nm}^{3}$ \\
\hline 7 & Volume of dry gases during combus- & $V_{\text {dry.g. }}=V_{\mathrm{g}}-V_{\mathrm{H} 2 \mathrm{O}}, \mathrm{nm}^{3} / \mathrm{nm}^{3}$ \\
\hline
\end{tabular}




\begin{tabular}{|c|c|c|}
\hline tion of $1 \mathrm{~nm}^{3}$ of fuel & $r_{0 . \mathrm{N} 2}=V_{0 . \mathrm{N} 2} / V_{\mathrm{g}} ; r_{0 . \mathrm{RO} 2}=V_{0 . \mathrm{RO} 2} / V_{\mathrm{g}} ; r_{0 . \mathrm{H} 2 \mathrm{O}}=V_{0 . \mathrm{H} 2 \mathrm{O}} / V_{\mathrm{g}}$ \\
\hline 9 & $\begin{array}{c}\text { Volume fractions of the combustion } \\
\text { products at the entrance HRSG } \\
\text { exclude their content in excess air }\end{array}$ & $\begin{array}{c}\text { Volume fraction of air in the com- } \\
\text { bustion products at the input of the } \\
\text { HRSG }\end{array}$ \\
\hline 10 & $\begin{array}{c}\text { Volume fractions of the combustion } \\
\text { products at the entrance with the } \\
\text { HRSG content of excess air: }\end{array}$ & $\begin{array}{c}r_{1 . \mathrm{N} 2}=1-r_{0 . \mathrm{N} 2}-r_{0 . \mathrm{NO} 2}-r_{0 . \mathrm{H} 2 \mathrm{O}} \\
r_{1 . \mathrm{Ar}}=r_{\mathrm{mAr} 2} \mathrm{r}_{0 . \mathrm{m}} ; r_{1 . \mathrm{H} 2 \mathrm{O}}=r_{0 . \mathrm{H} 2 \mathrm{O}}+r_{\mathrm{mH} 2 \mathrm{O}} r_{0 . \mathrm{Air}}\end{array}$ \\
\hline
\end{tabular}

The enthalpy of flue gases at the input of the HRSG is determined from the proportions of combustion products obtained in (10) and the set temperature $t_{0}$ and the pressure of the $P_{\mathrm{g}}$ using the function of the REFPROP program [11]

$$
\begin{aligned}
& h_{0}=\text { enthalpy("nitrogen";,;"; } r_{1 . \mathrm{N} 2} \text {;";";"CO2";,;"; } r_{1 . \mathrm{RO} 2} \text {;";";"oxygen";";"; } r_{1 . \mathrm{O} 2} \text {,";"; } \\
& \text { “argon";";"; } r_{1 . \mathrm{Ar}} \text {;";";"water",";"; } r_{1 . \mathrm{H} 2 \mathrm{O}} \text {;"TP";"SI"; } t_{0}+273,15 ; P_{\mathrm{g}} \text { ). }
\end{aligned}
$$

\subsection{Calculation of the composition of the combustion products and it en- thalpies at the input and outlet CHE}

\begin{tabular}{|c|c|c|}
\hline Index & Determined rate & Equation \\
\hline 12 & $\begin{array}{l}\text { Saturation pressure of water } \\
\text { vapor, } \mathrm{Pa}\end{array}$ & $P_{S 1}=\mathrm{f}\left(t_{1}\right), P_{S 2}=\mathrm{f}\left(t_{2}\right)$ \\
\hline 13 & $\begin{array}{c}\text { Partial water vapor pressure, } \\
\mathrm{Pa}\end{array}$ & $P_{1 . \mathrm{H} 2 \mathrm{O}}=P_{\mathrm{g}} r_{1 . \mathrm{H} 2 \mathrm{O},} P_{2 . \mathrm{H} 2 \mathrm{O}}=P_{\mathrm{g}} r_{2 . \mathrm{H} 2 \mathrm{O}}$ \\
\hline 14 & Dewpoint temperature, ${ }^{\circ} \mathrm{C}$ & $t_{\mathrm{dp} 1}=\mathrm{f}\left(P_{1 . \mathrm{H} 2 \mathrm{O}}\right), t_{\mathrm{dp} 2}=\mathrm{f}\left(P_{2 . \mathrm{H} 2 \mathrm{O}}\right)$ \\
\hline 15 & $\begin{array}{l}\text { Relative humidity water va- } \\
\text { por, } \%\end{array}$ & $\varphi_{1}=100 P_{1 . \mathrm{H} 2 \mathrm{O}} / P_{S 1}, \varphi_{2}=100 P_{2 . \mathrm{H} 2 \mathrm{O}} / P_{S 2}$. \\
\hline 16 & Volume fraction of dry gases & $r_{1 . \mathrm{dry} . \mathrm{g}}=1-r_{1 . \mathrm{H} 2 \mathrm{O},} r_{2 . \mathrm{dry} . \mathrm{g}}=1-r_{2 . \mathrm{H} 2 \mathrm{O}}$ \\
\hline 17 & $\begin{array}{l}\text { Partial pressure of dry gases, } \\
\qquad \mathrm{Pa}\end{array}$ & $P_{1 . \text { dry.g }}=P_{\mathrm{g}} r_{1 . \text { dry.g, }} P_{2 \text {.dry.g }}=P_{\mathrm{g}} r_{2 \text {.dry.g }}$ \\
\hline 18 & $\begin{array}{l}\text { Molar mass of dry flue gases, } \\
\mathrm{kg} / \mathrm{mol}\end{array}$ & $\begin{array}{c}\mu_{1 . d r y . g}=\mu_{\mathrm{N} 2} r_{1 . \mathrm{N} 2}+\mu_{\mathrm{O} 2} r_{1.02}+\mu_{\mathrm{CO} 2} r_{1 . \mathrm{CO} 2}+\mu_{\mathrm{Ar}} \mathrm{r}_{1 . \mathrm{Ar}}, \\
\mu_{2 . \mathrm{dry} . \mathrm{g}}=\mu_{\mathrm{N} 2} \mathrm{r}_{2 . \mathrm{N} 2}+\mu_{\mathrm{O} 2} \mathrm{r}_{2.02}+\mu_{\mathrm{CO} 2} \mathrm{r}_{2 . \mathrm{CO} 2}+\mu_{\mathrm{Ar}} \mathrm{r}_{2 . \mathrm{Ar}}\end{array}$ \\
\hline 19 & $\begin{array}{l}\text { Gas constant of dry flue gas- } \\
\text { es, } \mathrm{J} /(\mathrm{kg} \cdot \mathrm{K})\end{array}$ & $R_{1 . \text { dry.g }}=R / \mu_{1 . \text { dry.g, },} R_{2 \text {.dry.g }}=R / \mu_{2 \text {.dry.g. }}$ \\
\hline 20 & Coefficient & $K_{d l}=R_{1 . \text { dry. }} / R_{\mathrm{H} 2 \mathrm{O},} K_{d 2}=R_{2 \text {.dry. }} / R_{\mathrm{H} 2 \mathrm{O}}$ \\
\hline 21 & $\begin{array}{l}\text { Flue gas moisture content, } \\
\text { kg/kg.dry }\end{array}$ & $d_{1}=K_{d 1} P_{1 . \mathrm{H} 2 \mathrm{O}} /\left(P_{\mathrm{g}}-P_{1 . \mathrm{H} 2 \mathrm{O}}\right), d_{2}=K_{d} P_{2 . \mathrm{H} 2 \mathrm{O}} /\left(P_{\mathrm{g}}-P_{2 . \mathrm{H} 2 \mathrm{O}}\right)$ \\
\hline 22 & $\begin{array}{l}\text { Volume fraction of water } \\
\text { vapor at the outlet of the CHE }\end{array}$ & $r_{2 . \mathrm{H} 2 \mathrm{O} \cdot}=r_{1 . \mathrm{H} 2 \mathrm{O}}-\Delta d /\left(K_{d}+\Delta d\right)$. \\
\hline 23 & $\begin{array}{l}\text { Volumetric fractions of ele- } \\
\text { ments of dry flue gases at the } \\
\text { outlet of CHE }\end{array}$ & $r_{2 . i}=r_{1 . i} K_{d} /\left(K_{d}+\Delta d\right)$. \\
\hline 24 & $\begin{array}{l}\text { Enthalpy of flue gases at the } \\
\text { inlet of the CHE,kJ/kg }\end{array}$ & 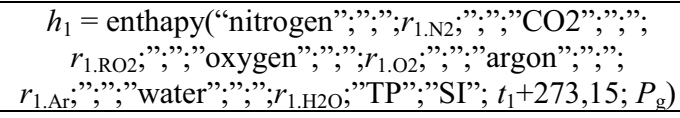 \\
\hline 25 & $\begin{array}{l}\text { Drop of moisture content in } \\
\text { the CHE, } \mathrm{kg} / \mathrm{kg} \text {.dry }\end{array}$ & $\Delta d=d_{2}-d_{1}$ \\
\hline 26 & $\begin{array}{l}\text { Enthalpy of flue gases at the } \\
\text { outlet of the CHE,kJ/kg }\end{array}$ & 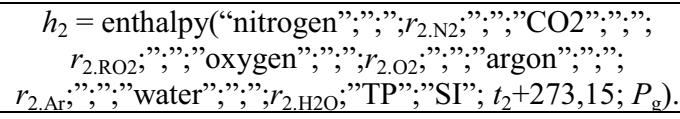 \\
\hline 27 & Enthalpy of the exhaust gases at & $h_{15.1}=$ enthalpy(“nitrogen";";"; $r_{1 . \mathrm{N} 2}$, ;";";”CO2";";”; \\
\hline
\end{tabular}

Table 2. Equations for properties of combustion products at the input and outlet of CHE. 


\begin{tabular}{|c|c|c|}
\hline & $\begin{array}{c}\text { a temperature of } 15^{\circ} \mathrm{C} \text { in the } \\
\text { HRSG without } \mathrm{CHE}, \mathrm{kJ} / \mathrm{kg}\end{array}$ & 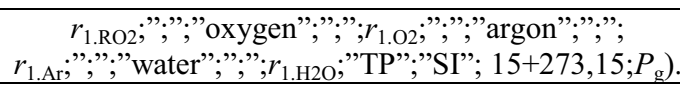 \\
\hline 28 & $\begin{array}{l}\text { Enthalpy of the exhaust gases } \\
\text { at a temperature of } 15^{\circ} \mathrm{C} \text { in } \\
\text { the HRSG with } \mathrm{CHE}, \mathrm{kJ} / \mathrm{kg}\end{array}$ & 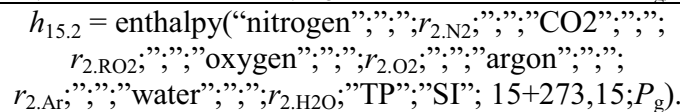 \\
\hline 29 & $\begin{array}{l}\text { Efficiency HRSG without } \\
\text { CHE }\end{array}$ & $\eta_{\text {HRSG. } 1}=\left(h_{0}-h_{1}\right) /\left(h_{0}-h_{15.1}\right)$ \\
\hline 30 & Efficiency HRSG with CHE & $\eta_{\mathrm{HRSG} .2}=\left(h_{0}-h_{2}\right) /\left(h_{0}-h_{15.2}\right)$ \\
\hline 31 & $\begin{array}{c}\text { Incrementation of efficiency } \\
\text { HRSG }\end{array}$ & $\Delta \eta_{\mathrm{HRSG}}=\eta_{\mathrm{HRSG} .2}-\eta_{\mathrm{HRSG} .1}$ \\
\hline
\end{tabular}

The model is implemented by the program in the Excel package with the calculation of the parameters of water, fuel and flue gases according to the functions of the REFPROP base [9].

\section{Results and analysis}

With this program, the calculations were carried out with the following input data: Composition of gas fuel, \%: $\mathrm{CH}_{4}=98.9 ; \mathrm{C}_{2} \mathrm{H}_{6}=0.94 ; \mathrm{C}_{3} \mathrm{H}_{8}=0.08 ; \mathrm{C}_{4} \mathrm{H}_{10}=0.08$.

Moisture of air $d_{\text {air }}=0.01 \mathrm{~kg} / \mathrm{kg}$.dry.

The temperature of the gases at the input of the HRSG $t_{0}=550^{\circ} \mathrm{C}$.

The gas pressure in HRSG $P_{\mathrm{g}}=10100 \mathrm{~Pa}$.

The temperature of flue gas at the input of the $\mathrm{CHE} t_{1}=100^{\circ} \mathrm{C}$.

Table 3. Summary.

\begin{tabular}{|c|c|c|c|c|c|c|c|c|}
\hline \multirow{2}{*}{$\begin{array}{c}\text { Temperatur } \\
\mathrm{e},{ }^{\circ} \mathrm{C} ; \\
r, \mathrm{~kJ} / \mathrm{kg}\end{array}$} & \multirow[b]{2}{*}{ Properties } & \multicolumn{7}{|c|}{$\alpha$} \\
\hline & & 1 & 1.5 & 2 & 2.5 & 3 & 3.5 & 4 \\
\hline$t_{0}=550$ & $h_{0}, \mathrm{~kJ} / \mathrm{kg}$ & 1258.6 & 1145.9 & $\begin{array}{c}1087 . \\
4\end{array}$ & 1051.6 & 1027.4 & $\begin{array}{c}101 \\
0.0 \\
\end{array}$ & $\begin{array}{c}996 . \\
9\end{array}$ \\
\hline \multirow{6}{*}{$t_{1}=100$} & $h_{1}, \mathrm{~kJ} / \mathrm{kg}$ & 718.2 & 623.8 & 574.8 & 544.8 & 524.6 & $\begin{array}{c}510 . \\
0\end{array}$ & $\begin{array}{c}499 . \\
0\end{array}$ \\
\hline & $d_{1}, \mathrm{~g} / \mathrm{kg} . \mathrm{dry}$ & 151.5 & 106.3 & 84.3 & 71.3 & 62.7 & 56.5 & 52.0 \\
\hline & $t_{\mathrm{dp1}},{ }^{\circ} \mathrm{C}$ & 60.4 & 54.0 & 49.8 & 46.8 & 44.5 & 42.7 & 41.2 \\
\hline & $\varphi, \%$ & 20.0 & 14.8 & 12.1 & 10.4 & 9.2 & 8.4 & 7.7 \\
\hline & $h_{15.1}, \mathrm{~kJ} / \mathrm{kg}$ & 622.9 & 531.1 & 483.5 & 454.4 & 434.7 & $\begin{array}{c}420 . \\
5\end{array}$ & $\begin{array}{c}409 . \\
8\end{array}$ \\
\hline & $\eta_{\text {HRSG. } 1}, \%$ & 85.0 & 84.9 & 84.9 & 84.9 & 84.8 & 84.8 & 84.8 \\
\hline \multirow{5}{*}{$\begin{array}{c}t_{2}=50 ; \\
r=2382\end{array}$} & $h_{2}, \mathrm{~kJ} / \mathrm{kg}$ & 509.9 & 517.4 & 522.7 & 526.5 & 529.2 & $\begin{array}{c}531 . \\
3\end{array}$ & $\begin{array}{c}532 . \\
9\end{array}$ \\
\hline & $\Delta d, \mathrm{~g} / \mathrm{kg} . \mathrm{dry}$ & 67.7 & 21.6 & -0.8 & -14.1 & -22.9 & $\begin{array}{c}- \\
29.2\end{array}$ & $\begin{array}{c}- \\
33.9\end{array}$ \\
\hline & $h_{15.2}, \mathrm{~kJ} / \mathrm{kg}$ & 472.6 & 479.9 & 485.1 & 488.7 & 491.4 & $\begin{array}{c}493 . \\
4\end{array}$ & $\begin{array}{c}494 . \\
9\end{array}$ \\
\hline & $\eta_{\text {HRSG.2 }}, \%$ & 95.3 & 94.4 & 93.7 & 93.3 & 92.9 & 92.7 & 92.4 \\
\hline & $\Delta \eta_{\text {HRSG }}, \%$ & 10.3 & 9.5 & 8.9 & 8.4 & 8.1 & 7.8 & 7.6 \\
\hline \multirow{5}{*}{$\begin{array}{c}t_{2}=40 ; \\
r=2406\end{array}$} & $h_{2}, \mathrm{~kJ} / \mathrm{kg}$ & 432.5 & 428.9 & 428.0 & 427.7 & 427.7 & $\begin{array}{c}427 . \\
7\end{array}$ & $\begin{array}{c}427 . \\
8\end{array}$ \\
\hline & $\Delta d, \mathrm{~g} /$ kg.dry & 104.0 & 58.4 & 36.1 & 22.9 & 14.2 & 8.0 & 3.4 \\
\hline & $h_{15.2}, \mathrm{~kJ} / \mathrm{kg}$ & 406.6 & 402.8 & 401.9 & 401.6 & 401.5 & $\begin{array}{c}401 . \\
6 \\
\end{array}$ & $\begin{array}{c}401 . \\
6\end{array}$ \\
\hline & $\eta_{\text {HRSG.2 }}, \%$ & 96.96 & 96.50 & 96.19 & 95.98 & 95.82 & $\begin{array}{c}95.7 \\
0 \\
\end{array}$ & $\begin{array}{c}95.6 \\
0\end{array}$ \\
\hline & $\Delta \eta_{\text {HRSG }}, \%$ & 11.9 & 11.6 & 11.3 & 11.1 & 11.0 & 10.9 & 10.8 \\
\hline
\end{tabular}




\begin{tabular}{|c|c|c|c|c|c|c|c|c|}
\hline \multirow{4}{*}{$\begin{array}{c}t_{2}=30 ; \\
r=2430\end{array}$} & $h_{2}, \mathrm{~kJ} / \mathrm{kg}$ & 387.7 & 378.5 & 374.4 & 372.2 & 370.7 & $\begin{array}{c}369 . \\
8\end{array}$ & $\begin{array}{c}369 . \\
1\end{array}$ \\
\cline { 2 - 9 } & $\Delta d, \mathrm{~g} / \mathrm{kg} . \mathrm{dry}$ & 125.1 & 79.6 & 57.5 & 44.4 & 35.7 & 29.5 & 24.9 \\
\cline { 2 - 9 } & $h_{15.2, \mathrm{~kJ} / \mathrm{kg}}$ & 372.4 & 363.1 & 359.0 & 356.8 & 355.3 & $\begin{array}{c}354 . \\
4\end{array}$ & $\begin{array}{c}353 . \\
6\end{array}$ \\
\cline { 2 - 9 } & $\eta_{\mathrm{HRSG} .2}, \%$ & 98.3 & 98.0 & 97.9 & 97.8 & 97.7 & 97.6 & 97.6 \\
\cline { 2 - 9 } & $\Delta \eta_{\mathrm{HRSG}}, \%$ & 13.3 & 13.1 & 13.0 & 12.9 & 12.9 & 12.8 & 12.8 \\
\hline \multirow{4}{*}{$\begin{array}{c}t_{2}=20 ; \\
r=2454\end{array}$} & $h_{2}, \mathrm{~kJ} / \mathrm{kg}$ & 359.0 & 346.8 & 341.0 & 337.7 & 335.6 & $\begin{array}{c}334 . \\
1\end{array}$ & $\begin{array}{c}332 . \\
9\end{array}$ \\
\cline { 2 - 9 } & $\Delta d, \mathrm{~g} / \mathrm{kg} . \mathrm{dry}$ & 137.2 & 91.9 & 69.8 & 56.7 & 48.1 & 41.9 & 37.4 \\
\cline { 2 - 9 } & $h_{15.2, \mathrm{~kJ} / \mathrm{kg}}$ & 353.9 & 341.7 & 336.0 & 332.6 & 330.5 & $\begin{array}{c}329 . \\
0\end{array}$ & $\begin{array}{c}327 . \\
8\end{array}$ \\
\cline { 2 - 9 } & $\eta_{\mathrm{HRSG} .2}, \%$ & 99.4 & 99.4 & 99.3 & 99.3 & 99.3 & 99.3 & 99.2 \\
\cline { 2 - 9 } & $\Delta \eta_{\mathrm{HRSG}}, \%$ & 14.4 & 14.4 & 14.4 & 14.4 & 14.4 & 14.4 & 14.4 \\
\hline
\end{tabular}

Figure 1 shows the dependence of the increase in the efficiency of the HRSG on $\alpha$ and $t_{2}$, and in Fig. 2 - dependence of the decrease in moisture content in the CHE from $\alpha$ and $t_{2}$.

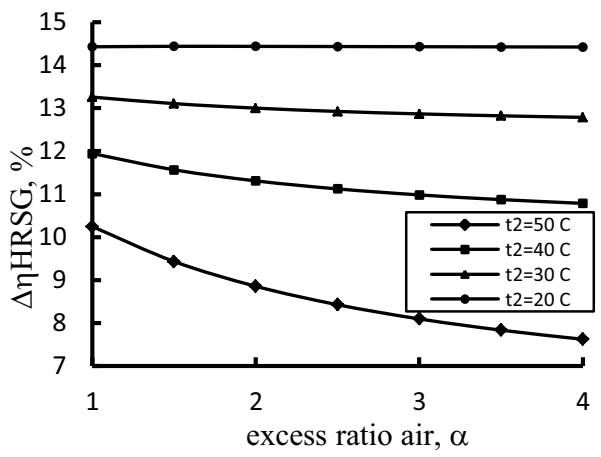

Fig.1. Dependence of the efficiency gains of HRSG.

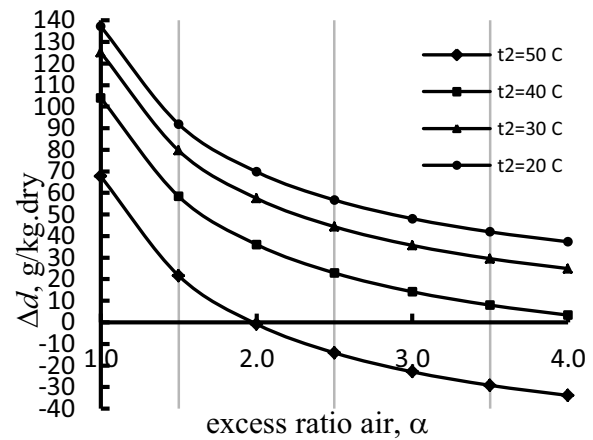

Fig. 2 -Dependence of decrease in moisture content in CHE.

The calculations based on the model showed that, depending on the temperature of the gases emerging from the CHE, the increase in the efficiency of the HRSG at the gas temperature at the outlet of the CHE $20^{\circ} \mathrm{C}$ is $14.4 \%$ and is independent of the air excess ratio $\alpha$. At a temperature of $30^{\circ} \mathrm{C}$, the efficiency gain drops slightly with an increase in the excess air coefficient from $13.3 \%$ at $\alpha=1$ to $12.8 \%$ for $\alpha=4$. At a temperature of $40^{\circ} \mathrm{C}$, the efficiency gain decreases from $11.8 \%$ at $\alpha=1$ to $10.8 \%$ for $\alpha=4$. At a temperature of $50^{\circ} \mathrm{C}$, the increase in efficiency gain decreases from $10.2 \%$ at $\alpha=1$ to $7.6 \%$ at $\alpha=4$. A strong drop in efficiency at a temperature of $50{ }^{\circ} \mathrm{C}$ is due to the fact that for $\alpha>1.9$ the 
temperature of the outgoing gases becomes higher than the dew point, so if the contact point is of the contact type, then there is no condensation of moisture, but evaporation.

\section{References}

1. A. Gabdullina, N. Galashov, S. Tsbuskiy, D. Melnikov, I. Asanov, A. Kiselev, Promising Direction of Perfection of the Utilization Combine Cycle Gas Turbine Units, 91, 01004 (2016)

2. D.V. Gvozdyakov, V.E. Gubin, Chemical and Petroleum Engineering, 51, 201 (2015)

3. S.A. Yankovsky, V.E. Gubin, A.A. Tolokolnikov, A.V. Zenkov, Strategic Technology (IFOST), 299 (2016)

4. S. Xiaojun, C. Defu, A. Brian, G. Jianmin, Int. J. Heat Mass Transfer, 54, 606 (2011)

5. K. Hwang, C. Song, K. Saito, S. Kawai. Applied Thermal Enjineering, 30, 2730 (2010)

6. N. Galashov, S. Tsibulskii, A. Matveev, V. Masjuk, EPJ Web Conf. 110, 01019 (2016)

7. Hazell D., Modeling and Optimization of Condensing Heat Exchangers for Cooling Boiler Flue Gas (Ph.D. Dissertation, Lehigh University, 2011)

8. N. Galashov, S. Tsibulskiy, A. Kiselev, MATEC Web Conf. 72, 01029 (2016)

9. N. Galashov, S. Tsibulskiy, T. Serova, EPJ Web Conf. 110, 01068 (2016)

10. E. Lemmon, M. Huber, M. McLinden, REFPROP, standard reference database 23, version 8.0, National Institute of Standard and Technology (2007) 